\title{
WIELOKULTUROWE INFLANTY POLSKIE. CZEŚĆ II: LITERATURA POLSKO-INFLANCKA
}

\author{
KRZYSZTOF ZAJAS
}

Poprzednie rozważania o historii dawnych Inflant Polskich były zaledwie, może nieco przydługim, wprowadzeniem do próby opisania kilku autorów, dzieł, zjawisk literackich, które pozwalam sobie objąć wspólnym mianem - literatura polsko-inflancka. Próby te skupiają się wokół rozumienia literatury - pewnych jej form i przejawów - nie jako środka do tworzenia lokalnie czy centralnie pojętej kultury, ale jako jej pochodnej, wywiedzionej z doświadczenia pewnej przestrzeni i zapisu tego doświadczenia w tekstach. Mamy tu do czynienia z literaturą zlokalizowaną peryferyjnie, pograniczną, podlegającą naciskom i determinantom wyróżnionym przeze mnie gdzie indziej jako cyrkulacja dyskursów ${ }^{1}$. W przypadku literatury polsko-inflanckiej dodatkowym czynnikiem jest fakt, że nie istnieje ona $\mathrm{w}$ historii piśmiennictwa polskiego - podobnie jak w historiografii jako osobny rozdział nie zaistniały Inflanty Polskie. Mamy więc do czynienia z odpadami, tekstami wyrzuconymi poza ramy dyskursu historycznoliterackiego, z błędami, albo raczej monstrami, jak Foucault nazywa twory krążące poza obrzeżami dyscypliny ${ }^{2}$. To właśnie te odpady pozwalają dostrzec system wykluczeń i zakazów, rządzący dyskursem historycznoliterackim; definicja błędu jest definicją prawdy.

${ }^{1}$ Zob. K. Zajas, Nieobecna kultura. Przypadek Inflant Polskich, rozdz. IV pt. „Dygresja druga. Pogranicze. Cyrkulacja dyskursów”, Kraków 2008, s. 243-279. Niniejszy tekst jest rozwinięciem tego oraz następnego rozdziału pt. „Literatura polsko-inflancka”.

${ }^{2}$ M. Foucault, Porzadek dyskursu, przeł. M. Kozłowski, Gdańsk 2002, s. 24-25. A zatem nasze badania inflanckie są rodzajem teratologii. 
Kiedyś na dalekich kresach inflanckich usłyszałem od człowieka pogranicza znamienną frazę: „Nieważne, jakim językiem człowiek mówi; ważne, kim się czuje". Odpowiadał w ten sposób na mój zarzut, iż uważa się za Polaka, miał babcię Polkę, a rozmawia ze mną po rosyjsku. Przyznawanie się do polskości należało tam do rytuału konwersacji z przybyszem z naszego kraju, stanowiło gest solidarności, sympatii i empati, ale także jakiś rodzaj samookreślenia, deklarację wspólnotowej identyfikacji, która w sytuacji niedookreślonej „tutejszości” przynosi chwilową ulgę. Bycie Polakiem na wielokulturowych terenach peryferyjnych daje poczucie przynależności do dalekiego, ale jednak swojskiego centrum. To pomaga psychicznie i konstytuuje wspólnotowo, nawet jeśli ma charakter tymczasowy i uwarunkowany czynnikami zewnętrznymi. Doświadczenie rozszczepienia na język i identyfikację narodową potwierdzało się tam na każdym kroku: słuchałem polskich pieśni, polskiej poezji i rozbrzmiewających wkoło polskich nazwisk, ale w prywatnych rozmowach uczestników dominowały dwa inne języki. Polskość nie wiązała się z używaniem języka polskiego jako własnego, domowego; była skutkiem wyboru narodowości, efektem poczynionej raz na zawsze bądź tylko chwilowo deklaracji przynależności, ale lokowała się poza mową. W popularnym wierszyku Władysława Bełzy „Kto ty jesteś? Polak mały”, tym katechizmie prawdziwego Polaka język jako warunek NIE WYSTĘPUJE, a polskość jest kwestią wiary („A w co wierzysz? W Polskę wierzę"). Jakby nadal na kresach nadal trwały rozbiory...

Powyższy inflancki przypadek stanowi modelową „sytuację pograniczną", $\mathrm{z}$ innym językiem używanym $\mathrm{w}$ domu, innym językiem urzędowym, a jeszcze innym językiem czytanej literatury. Tak zwana rozchwiana tożsamość na pograniczu nie daje się całkowicie zepchnąć na margines i mamy powody przypuszczać, że stoi ona w samym centrum kultury i literatury polskiej. Dość powiedzieć, że w takiej „sytuacji pograniczności” wychowywali się Mickiewicz, Słowacki, Miłosz... ${ }^{3}$

\section{Polsko-inflancka, czyli jaka?}

W zbitce ,inflancko-polska” nie chodzi o język, lecz o mentalność ludzi pogranicza kresowego, cały ten konstrukt ideowy składający się na stereotyp polskiego patrioty. Polskość oznaczała wybór przynależności narodowej, wyznaniowej, językowej, często także klasowej i politycznej (urzędy szlacheckie). Ujawnia się w niej także pewne zorientowanie przestrzenne - w kierunku zachodnim. Być Polakiem na kresach wschodnich oznaczało: czuć się człowiekiem Zachodu, zachodniochrześcijańskiej kultury, cywilizowanej Europy. W tle stały również roszczenia historyczne, polityczne, prawne czy obyczajowe. Sam fakt deklarowania przynależności do

\footnotetext{
${ }^{3}$ Szerzej mówię o tym gdzie indziej, zob.: K. Zajas, Uchwycić nieuchwytne. Pożytki z badań pogranicznych, „Wielogłos” $2014 \mathrm{nr}$ 2(20), s. 91-101.
} 
wspólnoty narodowej jest już charakterystyczny - w „centrum” takie deklaracje są po prostu zbędne.

Kulturowo rozumiane jest tu również pojęcie „literatury”, poszerzonej o teksty historyczne, folklorystyczne, eseje wspomnieniowe, a nawet teksty przyrodoznawcze. W ich doborze kierowałem się zasadą dominacji nie tyle funkcji estetycznej, ile uruchamiających je dyskursów, tak więc bliżej stąd do pojęcia piśmiennictwa, niż literatury. Za motto owego poszerzenia niech posłuży uwaga Stephena Greenblatta o tym, że obecna humanistyka „oddziela nauczanie historii od nauczania literatury, tak jakby to były dwie odrębne dziedziny",

\section{Konstancja Benisławska}

Stolnikowa inflancka Konstancja z Ryków Benisławska (1747-1806) wywodziła się ze starej niemiecko-bałtyckiej rodziny, zadomowionej w Inflantach od początku kolonizacji (rycerze de Recke od 1209 r. współtworzyli Zakon Kawalerów Mieczowych), a w województwie inflanckim od początku jego istnienia, jako że w $1568 \mathrm{r}$. miało miejsce pierwsze nadanie lennych dóbr Drycany, Pilcyny i Strużany dla Ernesta de Ryk od króla Zygmunta Augusta ${ }^{5}$. Historycy literatury i biografiści do dzisiaj powtarzają legendę o wykształceniu i niezwykłej urodzie stolnikowej, którą podziwiać można na zachowanym do dzisiaj portrecie poetki ${ }^{6}$. Poza tym niewiele o niej wiemy; bratem męża był lichy wierszokleta Konstanty Benisławski, autor kompromitującego dziełka na cześć Katarzyny II, a ich kuzynem - jezuita Jan Benisławski, biskup mohylewski ${ }^{7}$. W roku $1776 \mathrm{w}$ Wilnie wydała zbiorek poetycki pt. Pieśni sobie śpiewane od Konstancji z Ryków Benisławskiej, stolnikowej Księstwa Inflanckiego, za naleganiem przyjaciót z cienia wiejskiego na jaśnia wydane i wpisywał się w poetykę oraz tematykę saskiego baroku, choć był to już czas stanisławowskiego oświecenia. Pieśni mają przemyślany układ: podziałowi tematycznemu na trzy części odpowiada zróżnicowanie metryczne: księga pierwsza (Ojcze nasz)

\footnotetext{
${ }^{4}$ S. Greenblatt, Poetyka kulturowa, red. K. Kujawińska-Courtney, Kraków 2006, s. 154.

${ }^{5}$ Gustaw Manteuffel w Inflantach Polskich utożsamia tę rodzinę z niemiecką von der Recke, by następnie zaprzeczyć temu w O starodawnej szlachcie krzyżacko-rycerskiej... i przypisywać jej odrębne, polskie korzenie.

${ }^{6}$ Portret ten miałem okazję obejrzeć dzięki uprzejmości państwa Anny Manteuffel-Szarotowej i Tomasza Szarotów, w których posiadaniu się znajduje.

${ }^{7}$ Tytuł poematu K. Benisławskiego: Pienia całodzienne i całonocne na przybycie do krajów swych białorosyjskich najjaśniejszej Imperatorowej Katarzyny II, cesarzowej, stworzycielki, prawodawczyni i matki całej Rosji, od poddaństwa prowincji dźwińskiej wierszem królewskim złożone, Wilno 1780; Jan Benisławski także imał się pióra, wydał m.in. Rozmyślania dla księży świeckich o powinnościach chrześcijańskich z listów i Ewangelii wzięte, Połock 1799-1802 (2 tomy), które są właściwie thumaczeniem $\mathrm{z} \mathrm{j}$. francuskiego.
} 
pisana jest trzynastozgłoskowcem (7+6), księga druga (Zdrowaś Mario) jedenastozgłoskowcem (5+6), natomiast w księdze trzeciej odnajdziemy metrum swobodniejsze, niczym wprawki poetyckie na bazie pieśni Jana Kochanowskiego. Rygory porządku tematycznego i metrycznego nadają całości formę harmonijną, przemyślaną, niemal poematową.

Obfitość i ładunek emocjonalny potężnego wyznania wiary, wyrażonego w kaskadach natchnionych strof, powodują, że zbiorek Benisławskiej mógłby posłużyć za modelowy przykład zarówno najczystszej mistyki chrześcijańskiej, jak i religianckiej bigoterii czy dewocji. Uniesienia religijne nadają tym wierszom silnie osobisty i intymny charakter, i stanowią rodzaj ucieczki od świata, przejścia poprzez mistyczny wzlot $w$ inną rzeczywistość, odcięcia od doczesności. Trudno było zgodzić się krytykom i historykom literatury co do wartości tego zbiorku. Nazwano Pieśni „najdziwniejszą może książką w literaturze polskiej XVIII wieku", dostrzegano w niej anachronizm i irracjonalność, znak ubóstwa warsztatowego, a nawet wręcz ograniczenia intelektualnego autorki. Dawniej największą wartość widziano w księdze pierwszej, współcześni doceniają raczej część ostatnią - najswobodniejszą i najbardziej intymną ${ }^{9}$. Wskazywano na związki tej poezji z barokową mistyką naśladowców św. Teresy z Avila i św. Jana od Krzyża, przyznawano Benisławskiej palmę pierwszeństwa $\mathrm{w}$ przedromantycznej poezji religijnej ${ }^{10}$. Spychana $\mathrm{w}$ zapomnienie i zawieruszona - Konstancja Benisławska znowu dzisiaj zdumiewa jako zjawisko duchowe, i jako jedna z pierwszych kobiet-literatek.

Poezja ta daje się czytać na dwóch poziomach. Pierwszy z nich - indywidualny, osobisty, intymny - pozwala wejść w głębokie pokłady przeżyć religijnych osoby żarliwie wierzącej, niemal odurzonej wiarą ${ }^{11}$. Zapis doznań przypomina nieopanowany słowotok, erupcję słów obsesyjnie krążących wokół jednego tematu, a nawet wokół jednej formułki. Każda linijka codziennej, powszechnej i wydawałoby się, mechanicznie odmawianej modlitwy, wyzwala niezwykłą energię wierszotwórczą:

Ojcze nasz! Bo azaliż Ty nie Ojcem moim,

Któryś mię posiadł, stworzył dziwnym dziełem Twoim,

Którego Syn rodzony równy Ci od wieka

Stał się mym bratem, bratem grzesznego człowieka?

\footnotetext{
${ }^{8}$ Zob. W. Borowy, O poezji polskiej w wieku XVIII, Kraków 1978, s. 189.

${ }^{9}$ Zob.: Grażyna Borkowska, Małgorzata Czermińska, Ursula Phillips, Pisarki polskie od średniowiecza do wspótczesności. Przewodnik, Gdańsk 2000, s. 32-34, K. Benisławska, Pieśni sobie śpiewane, wstęp: T. Chachulski, Warszawa 2000, s. 18.

${ }^{10}$ Pełny wykaz aluzji, zapożyczeń i naśladowań zastosowanych przez Benisławską podaje T. Chachulski, op. cit., s. 13-18.

${ }^{11}$ Zygmunt Freud uważał tego typu stany religijne za odmianę histerii. Zob. Z. Freud, Histeria i lęk, przeł. Robert Reszke, KR, Warszawa 2001, zwłaszcza w posłowiu do Fragmentu analizy pewnej histerii, s. 155-163.
} 
Ojcze nasz! Ach, jak wielką córką mię zdziałałeś,

Gdy tak wielkiego Syna za brata mi dałeś!

Prawdziwie śmiało rzekę: tym człeka do góry

Wzniosłeś, Boże, nad wszystkie Serafinów chóry ${ }^{12}$.

Tytuł Pieśni sobie śpiewane wskazuje na prywatny, konfesyjny charakter tych wierszy, które podobno pierwotnie nie były wcale przeznaczone do upublicznienia. Są one niezwykle rozbudowaną inwokacją, miejscami przechodzącą w solilokwia, często opartą na pytaniach retorycznych, patetycznych wykrzyknikach i niezliczonych powtórzeniach, wyraźnie jednak nieliczącą się także z psychologią odbioru ${ }^{13}$. Można powiedzieć, że Pieśni stanowią swobodny, nieskrępowany wyraz żarliwych uczuć religijnych, ujętych w regularne wiersze sylabiczne. Cały zbiorek przybiera kształt trzyczęściowego modlitewnika, z wierszami poświęconymi Bogu Ojcu, Matce Boskiej oraz wierszami-modlitwami okolicznościowymi. Nie ma mowy o żadnej liryce maski czy dystansie, tożsamość podmiotu lirycznego i autorki wydaje się niewątpliwa.

W części trzeciej najwyraźniej do głosu dochodzą stany uniesienia mistycznego graniczące z ekstazą, tęskniące do oderwania od ziemi, na wzór mistyków hiszpańskich XVII w., jak to słychać w Pieśni 8, w której Wyraża się potęga miłości ku Chrystusowi:

Spraw, bym miłością Twą, jakoś jest godzien,

Barziej a barziej ja gorzała codzień,

Iżby się dusza po rozłące ciała

Godniejszą świętych Twych obłapów stała.

(...)

O dobry Jezu, spraw, abym dla Ciebie

I świat wzgardzała, i wzgardzała siebie.

Spraw, aby wszystko prócz Ciebie trąciło,

Co jest na ziemi, zgnilizną przegniłą.

Lub złote słońce dzień sieje po świecie,

Lubo noc czarna sen do oczu gniecie,

Niech dusza moja doma i w gościnie

Cię szuka, wzywa, opiewa jedynie! $!^{14}$

Autorka nie obawia się ani ryzykownych zestawień (,zgnilizna przegniła”), ani ekscentrycznych dwuznaczności, korzystających z bogatej sfery erotyki („święte

${ }^{12}$ K. Benisławska, Pieśni sobie śpiewane, Universitas, Kraków 2003, s. 19-20.

${ }^{13}$ Każdemu z wersów obu modlitw, Ojcze nasz i Zdrowaś Mario, poświęca autorka od 30 do 70 zwrotek. Rekordzista, wers Przyjdź Królestwo Twoje! w pieśni IV księgi pierwszej, zainspirował aż 74 strofy!

${ }^{14}$ K. Benisławska, op. cit., s. 130. 
Twe obłapy"), co dość często przydarza się literaturze mistycznej. Niemniej ryzykowne wydają się prośby poetki o to, by „i świat wzgardzała, i wzgardzała siebie”, wychodzące spod ręki znakomitej ponoć zarządczyni i matki całej gromadki dzieci. Świat jako „zgnilizna przegniła” jest tu raczej typową figurą chrześcijańskiej vanitas, niż wyrazem niechęci do codziennych obowiązków stolnikowej inflanckiej.

Dostrzec się daje radykalna nieprzystawalność pomiędzy społeczną i rodzinną sytuacją Benisławskiej, a kondycją duchową bohaterki Pieśni sobie śpiewanych. W innym wymiarze sytuuje się religijne uniesienie św. Teresy od Jezusa - natchnionej zakonnicy, reformatorki i założycielki klasztorów - a w innym nieopanowane, ekstatyczne wybuchy religijności u statecznej matrony, która w ciągu dnia dogląda doczesności, by w wieczornych modlitwach ją przeklinać jako „światową próżność”.

A oto drugi poziom odczytania Benisławskiej. Stare rody rycerskie Inflant Polskich w większości przechodziły na katolicyzm dopiero w 2 połowie XVIII w., praktycznie po odpadnięciu tego terytorium od Polski, czyli wraz z narastającą groźbą rusyfikacji. Według Gustawa Manteuffla rodzina Ryków drycańskich spolonizowała się dosyć późno ${ }^{15}$, z czego możemy wnosić, że Konstancja - podobnie jak św. Teresa z Avila, która pochodziła z hiszpańskich Żydów - była neofitką. Z kolei polonizacja Bałto-Niemców najczęściej odbywała się drogą małżeństw z szlachtą pochodzenia polsko-litewskiego, co pociągało za sobą z reguły zmianę wyznania. Sporą część życia spędziła Konstancja Benisławska w Posiniu (łot. Pasiene), majątku rodowym Benisławskich, niegdysiejszej własności polsko-inflanckich Borchów. Tutaj stolnikowa została pochowana, w podziemiach kościoła posińskiego, gdzie można oglądać jej grobowiec ${ }^{16}$. Posiń leży na najdalej na wschód wysuniętych rubieżach Inflant Polskich, tuż przy granicy z Rosją; z okien okazałego dworu, ponad drzewami parku, widać zarośla wzdłuż rzeki Siny (łot. Sienāja, ros. Sinjaja, od niej Posiń wziął nazwę), za którą od wieków rozpościerały się dla tutejszych gospodarzy ziemie wschodnich barbarzyńców najeżdżających inflancką kolonię zachodniego chrześcijaństwa. Jeżeli sytuację kościoła katolickiego na kresach wschodnich zwykło się określać jako trudną i złożoną, to w domowych stronach pani stolnikowej napięcia te sięgały zenitu. Po roku 1772 katolicy inflanccy faktycznie znaleźli się w sytuacji oblężonej twierdzy, a ich najpowszechniejszą reakcją na ten stan rzeczy było fundowanie kościołów, które w XVIII i XIX w. przybrało doprawdy imponujące rozmiary.

Lektura wierszy Benisławskiej nie jest łatwa. Wymaga od czytelnika albo złączenia $\mathrm{z}$ autorką we wspólnej modlitwie, albo maksymalnego dystansu, wyjścia poza narzucony przez nią dyskurs $\mathrm{w}$ stronę analizy kulturowej. Pieśni sobie śpiewane

${ }^{15}$ G. Manteuffel, Pisma wybrane, t. I, Inflanty Polskie. Listy znad Bałtyku, red. K. Zajas, Kraków 2009, s. 90.

${ }^{16} \mathrm{~W} 2011$ roku w posińskim kościele parafialnym odsłonięto tablicę pamiątkową poświęconą Konstancji z Ryków Benisławskiej. 
mają swój wymiar religijny - hermetyczny, mistyczny, metafizyczny - oraz wymiar wyznaniowy - społeczny, historyczny, peryferyjny, antropologiczny. Indywidualne, niepowtarzalne przeżycie religijne nałożone jest na zapis polsko-inflanckiego doświadczenia zbiorowego, ulokowanego w konkretnym miejscu i czasie, którego ramy wyznacza wyznaniowo rozproszone pogranicze.

\section{Rubon}

Do ciekawych fenomenów kultury polsko-inflanckiej należy również siedmioletnie funkcjonowanie pisma „Rubon” pod redakcją Kazimierza Bujnickiego. Ukazywało się nieregularnie w latach 1842-1849 i obejmuje 10 grubych numerów, podzielonych na trzy nierówne działy: „Rzeczy poważne”, „Literatura” oraz „Rzeczy użyteczne". Jednym z najważniejszych kontekstów ideowych dla redakcji, kierowanej przez Kazimierza Bujnickiego, był regionalizm. W pierwszych słowach Od Wydawcy region ten został zarysowany bardzo konkretnie, zarówno w odniesieniu do autorów:

...pismo niniejsze w swym zawiązku zbiorem jest pracy małej liczby osób jednej prawie tylko prowincji; jest to, jakby powiedzieć, wiązka samorodnych kwiatów na brzegach Dźwiny uszczknionych... ${ }^{17}$

Prawdziwy cel nie mógł zostać sformułowany wprost z powodów cenzuralny $\mathrm{ch}^{18}$. Z deklaracji redaktorów wynikało, że program edukacyjny dotyczył generalnie dwóch spraw, zbieżnych i przeciwstawnych zarazem: ochrony inflanckiej polskości i zachowania odrębności Inflant Polskich. $Z$ jednej strony mamy tu bowiem odwołanie do wspólnoty narodowej w duchu Mickiewiczowskim, z drugiej natomiast różnicę i inność, podkreślającą specyfikę, w czym łatwo odczytać tendencję do uruchamiania wartości peryferyjnej Inflant Polskich.

Punktem wyjścia dla autorów pisma - co w przypadku Inflant Polskich jest już regułą - było ustalenie granic i historii przedmiotu badań. Nazwa czasopisma pochodziła od starożytnej nazwy Rubo, pojawiającej się u Ptolemeusza i mającej oznaczać Dźwinę, a zatem rzeka stanowiła główny punkt odniesienia, oś peryferii, co potwierdza umieszczony na wstępie wiersz Ignacego Chrapowickiego:

Na brzegach Niemna, Wilii, słychać bardów pienie,

Ponad Wisłą kwitnące wznoszą się osady,

A tu, pusto w około - i głuche milczenie,

Jak gdyby mię odbiegły mych synów gromady.

17 „Rubon. Pismo poświęcone pożytecznej rozrywce”, wyd. K. Bujnicki, Wilno 1842, t. 1, s. VI.

${ }^{18}$ Obawy przed cenzurą widać w ostatnim zdaniu przedmowy, gdzie Bujnicki zapewnia, że „Rubon” nie jest „pismem periodycznym”. Przepisy zezwalały na ukazywanie się na terenach zaboru czasopism wyłącznie nieregularnych. 
Przed laty krwawe łuny barwiły me tonie,

Pożar zamków inflanckich i siół ruskich dzieci,

A teraz cichy księżyc spokojnie w nich świeci,

I zadumane gwiazdy kąpią się w mym łonie. [R I, 1-2]

Wiersz stanowi liryczną deklarację programową pisma, z historyczną identyfikacją (zamki inflanckie), troską o rozwój regionu (żegluga), i arkadyjskim mitem rzeki domowej, która troszczy się o swych podopiecznych (synów gromady).

Oprócz poetyckiego wyznaczenia osi centralnej, axis mundi, autorzy definiowali także swój region jako specyficzne pole badań naukowych. Dział „Rzeczy poważne” wypełniają przyrodnicze opisy inflanckich fenomenów, więc znajdujemy tutaj szkice historyczne, analizy znalezisk archeologicznych, charakterystyki mieszkańców itp. Identyfikacja z krzyżacko-inflancką przeszłością krainy najwyraźniej autorom nie przeszkadzała, wręcz przeciwnie, pozwalała budować swoistą ciągłość historyczną. Tak wygląda np. szkic hrabiego Adama Platera poświęcony historii warowni dyneburskiej, który w centrum uwagi stawia zamek jako ośrodek lokalnej administracji, miejsce organizujące publiczną działalność. Historyczna identyfikacja inflancka nie mogła się obejść bez pracy, nazwanej tutaj „ustanawianiem Inflant”, co sformułował Józef Plater:

Kiedy ta mała prowincja, co ją polskimi Inflantami nazywają, w połączeniu z Biało-rusią ruszać się zaczyna życiem literackim, kiedy nie tylko, że książki wydaje, ale nadto, zdobyła się na ów pszczelnik, w którym składając miodek prac swoich zbierany po krajowym kwieciu, może go innych ziomków swoich gustowi przedstawić; nie od rzeczy będzie wskazać, czym jest ta mała kraina, nie znana od wielu, od wielu też za jedno co ryskie Inflanty miana [R II, 49].

Słychać tu potwierdzenie tezy powtarzanej później przez Gustawa Manteuffla, że Inflanty i Inflanty Polskie to dwie różne krainy. Józef Plater rozpoczyna swój tekst w dyskursie regionalizmu (krajowe kwiecie), w części merytorycznej przechodzi jednak do porządku wyznaniowego, przekształcając zapowiadany zarys w przegląd kościołów i fundujących je rodów. Zdradza tym samym przynależność klasową i konfesyjną. Natomiast z całą powagą należy potraktować radosne powitanie przez niego lokalnej inicjatywy literackiej; sam fakt pisania i publikowania po polsku tekstów w Inflantach i o Inflantach był dla autorów nowym i ważnym wydarzeniem. Polskojęzyczne czasopismo kulturalne otwierało nieoczekiwane możliwości dla realizacji starej potrzeby - ontologicznego wzmacniania krainy. Miejsce nieopisane nie istnieje, a „Rubon” oferował swoje łamy wszystkim tym, którzy chcieli opisywać Inflanty Polskie.

Płody literackie zamieszczane w „Rubonie” także doskonale mieściły się w ramach dyskursu regionalizmu, ciekawe ą natomiast przekreślenia i wątpliwości co do historii i kultury rodzimej ziemi autorów „Rubonu”, składającej się z wielu nieprzystających 
do siebie wątków. Poemat Michała Borcha (1806-1881) pt. Gercike sięga do źródeł inflanckiej kolonizacji i ostatnich chwil pogańskiej stolicy Letgalów, tytułowego Gercike, zburzonego podczas najazdu rycerzy Zakonu. W na poły mitycznej opowieści autor skupia się na nostalgicznej historii o pierwotnych mieszkańcach regionu, przodkach autochtonów, z którymi najwyraźniej sam się utożsamia:

Jam to doznał niedawno. - Księżyc lśnił bladawy;

Z tej strony gercikowe srebrzyły się wzgórza;

Tam, Dźwina biegła szemrząc imię Gorysławy.

Cisza była na niebie, - w duszy tylko burza!

Wtem, wierna towarzyszka, spadek po dudarzu,

Stara gęśla, leżąca przy mnie na murawie

Jękła smutnie - wiatr pobiegł po jodłach, cmentarzu,

Rzeka chyżej pomknęła, - dziergacz uciął w trawie; [R I, 62]

Punkt wyjścia wydaje się Mickiewiczowski, a narrator poematu stylizowany jest na Wajdelotę. Jednakowoż opowieść nie przybiera konkretnego kształtu, na poziomie wydarzeń nie dzieje się prawie nic. Gdy kraj zostaje spustoszony, a żona z dzieckiem uprowadzona przez rycerzy „w białych płaszczach, z krzyżem na ramieniu” - główny bohater, łatgalski wódz Wissewald, śni o wielkich czynach, zemście i odbudowaniu potęgi swego ludu. Ze snu budzi się jednak tylko po to, by... zapłakać. Jego wielki sen nie zmierza do niczego, nie ma przełożenia emocji na działanie, w końcu Wissewald odchodzi w niebyt i niejasną legendę:

„O Gercike! - o grodzie niegdyś okazały;

Ojczyzno przodków moich, kraju dziś jałowy!

(...)

I tułam się, gdy wszystkie twoje legły syny,

I sam jeden, dziś płaczę, na twoim pogrzebie!"

Rzekł - umilkł - otarł oko i poszedł przez pola. [R I, 68]

Historia nie ma wyrazistej formy, przedstawia mgliście jakieś odległe wydarzenia, a właściwie zaledwie zarysy wydarzeń, których cel i sens pozostał nierozpoznany. Nieznane są nawet dalsze podstawowe rozstrzygnięcia ideowe głównego bohatera, istnieje on w poemacie Michała Borcha jako niewyraźny, rozmyty znak:

O losach jego dalszych nie pytajcie u mnie.

Jedni mówią, że wkrótce zmogła go niedola,

Że skonał, wrogom swoim zawsze grożąc dumnie.

Inni znów, są tacy jeszcze, co głoszą przeciwnie:

Że przejednał Biskupa, - Niemcom był życzliwy,

Z żoną wrócił na Gercik, - chrzcił się; a co dziwniéj,

Braci Pogan wojował, i umarł - szczęśliwy! - [R I, 68] 
Trudno tu mówić o przesłaniu ideowym, poemat pozostaje pusty. Brak konkretów pozbawia historię sensu, opowieść zmienia się w opowiastkę, w dodatku bez morału i wniosków praktycznych. Coś kiedyś się tu, w Inflantach, działo, pozostały jakieś ślady w wykopaliskach i pieśni gminnej, próżno jednak opierać na nich historiograficzną czy mitologiczną konstrukcję. Ułomność inflanckiej reprezentacji przejawia się w braku jednorodnych faktów, którymi przemawiałaby historia. Jedynym uchwytnym odniesieniem staje się sfera emotywna narratora, jego pragnienie, by coś z tej mglistej przeszłości pozostawić. Imperatyw zastępuje fakt:

Ach, pójdźmy, gęśli moja! pójdźmy spajać wątki

Znikłego nam obrazu; - i siły obiema

raz jeszcze go zwołujmy, ty - nutą pamiątki;

Ja, - głosem Wajdeloty, co ołtarzów nie ma! [R I, 69]

Narrator nie rozumie historycznych zdarzeń, próbuje wzbudzić przeszłość w jakiejś mglistej formie i zarazem zdaje sobie sprawę ze swej niewiedzy i bezradności. Tajemnica przeszłych wydarzeń odsłoni się „gdy Bóg zechce”, co można odczytać jako: w zupełnie zmienionych okolicznościach, w innej rzeczywistości. Teraźniejszość uniemożliwia odczytanie znaków, jakie przeszłość pozostawiła na inflanckiej ziemi.

Sens poematu Michała Borcha możemy też odczytać w innym, bardziej wielokulturowym kontekście. Niepewność co do znaczenia przeszłości dyktuje lęk przed brakiem lokalnej legitymizacji. W rzeczy samej, narrator wyraźnie sympatyzuje z pogańskim bohaterem, próbuje wczuwać się w jego dramatyczne położenie, jego dziedzictwa szuka w niejasno przemawiającej historii. Ale jednocześnie zdradza się z przeczuciem, że to nie jego historia, że dotyka dziejów obcych. Na początku poematu Gercike w wyobraźni narratora przesuwają się obrazy historyczne pochodzące z cudzej sfery kulturowej, nieznanej, wymagającej dopowiedzenia. Do wersu „Jakież to mury z trzaskiem walą się do Dźwiny?” Borch dołącza przypisy, by wyjaśnić historyczne źródła fabuły, pozostaje ona jednak nieodgadniona, nieczytelna, przemawia znakami nieprzekładalnymi na doświadczenie kulturowe podmiotu. Jej przeczytanie wymaga zmiany perspektywy, wykroczenia poza własny, polskoinflancki horyzont egzystencji.

Znamiona podobnej nieczytelności nosi cała dawna kultura. Autor umieścił w przypisach na końcu listę bóstw, postaci i faktów historycznych, nazw geograficznych i mitologicznych, które mają wyjaśnić kontekst kulturowy dzieła, a właściwie go ustalić. Borch powtarza tu gest projektowania tła kulturowego, jest w tym jednak więcej twórczości poetyckiej, ustanawiania przez intencję, niż umocowania historii w faktach.

W podobne konteksty wpisuje się mini-poemat $N a$ dąb $w$ Inflantach $\mathrm{z}$ drugiego tomu „Rubonu”, podpisany inicjałami P.A. i również w pierwszym odczytaniu odwołujący się do regionalizmu Mickiewiczowskiego. Zgodnie z sugestią zawartą 
w tytule, za przedmiot poematu autor obrał sobie dąb Baublis, dodając w przypisie zapewne w obronie przed posądzeniem o plagiat - że tak zwali swe święte dęby dawni Łotysze [R II, 81]. Inflancki Baublis stoi w „dawnym Łotyszów kraju” i nosi w sobie zapisaną historię wielu narodów:

Powiedz mi (...) dębie ubóstwiany,

Coś przez niemało wieków patrzał na narody,

Na przemienne ich losy, ich zbrodnie i cnoty,

Jaka była ich chwała, jakie ich przygody,

Gdzie walczyły, gdzie legły mordercze ich roty? [R II, 77]

Podobnie jak u Borcha, narrator jest przybyszem, wędrowcem, który próbuje dotrzeć do źródeł tutejszej kultury, odcyfrować znaczenia wpisane w miejsce. Jego inność kulturowa przejawia się w niewiedzy i dezorientacji, jakby znalazł się przypadkowo w obcym miejscu:

Ach, opowiedz mi dzieje ludów tej krainy,

Czyich strzeżesz tu prochów, czyje te mogiły?

Jakichże tam Zamczysków sterczą rozwaliny?

Gdzie są te straszne działa, co w te mury biły? [R II, 78]

Moda na regionalizm miała na wschodzie swoje silne reperkusje, natomiast w Inflantach objawiała ten dodatkowy walor, że za jej pomocą można było postawić kilka zasadniczych pytań o charakterze tożsamościowym. Autorami piszącymi w „Rubonie” byli niemal bez wyjątku ludzie tutejsi, urodzeni i zadomowieni w Inflantach Polskich, a zatem będący u siebie. Powyższy zestaw pytań demaskuje tę niepewną „swojskość”, wystawia ją na próbę w obliczu złożonej i wielokulturowej przeszłości.

Faktograficznych odpowiedzi na pytania narratora łatwo udzielić na podstawie tekstów historycznych, których lektura nieobca jest autorowi, jak wynika z przypisów. Kurhany zawierają prochy Liwów i Łatgalów, zamki należały do Zakonu Krzyżacko-Inflanckiego, a w ich mury biły działa polskie, rosyjskie i szwedzkie. Narratorowi jednak nie o takie odpowiedzi chodzi. On pyta o więzi pomiędzy indywidualnym doświadczeniem miejsca urodzenia, a zbiorowym doświadczeniem specyfiki regionu. Pyta o ciągłość, o to, co go łączy z rodzinnymi Inflantami. Pytanie o tożsamość jest zarazem jej zakwestionowaniem, zgłoszeniem problemu i potrzeby identyfikacji, o czym świadczą poszukiwania mitologiczne:

Jaką ci cześć, mój dębie, dawały narody, I bóstwom, których strzegłeś? Gdzie jest Perkun groźny,

Nieubłagany Poklus i bóg Atrymp młody?

Sprawca zaburzeń morskich, Gardoajtis mroźny? - 
i następujące tuż za nimi poszukiwania historyczne:

Znałżeś szanowny Baubli, znałżeś ty Mejnharda,

Co twych bogów zwyciężył? Bertolda śmiałego,

Któremu śmierć zadała Liwów włócznia twarda? -

Widziałżeś wodza Kobbe w bitwie poległego,

I łuna gorejących ruskich Książąt grodów,

Zbrojnego Kokenois i Gercike gmachów,

Zburzonych przez rycerzy germańskich narodów? [R II, 78]

Żądana odpowiedź nie może paść. Do konstytutywnych cech „swojskości” danego terytorium należy jej nieprzekazywalność. Kultura lokalna jest hermetyczna i nie otwiera się przy użyciu naukowych - mitologicznych i historiograficznych - kluczy. Gdy dąb próbuje odpowiadać, zostaje powalony piorunem przez Perkuna. Starodawna Łatgalia zazdrośnie strzeże swojej tajemnicy miejsca. Przybysz pozostaje sam ze swoją wątpliwością, najpierw zignorowany, później przestraszony i przpędzony. Ziemia inflancka nie tylko ukrywa przed wędrowcem swe sekrety; budzi strach i odrazę, zniechęca go i grozi. Nawet jeśli przeszłość coś znaczy i z mowy dębu mogłaby wyniknąć jakaś jednoznaczna prawda, najpotężniejsze bóstwa nie pozwalają tych znaczeń zdradzić. Kultura nie ma swej reprezentacji, nie jest wymienialna na żadne dyskursywne pojęcia. Zamyka się w milczeniu, którego nie wolno naruszyć.

Pierwotna tożsamość Inflant została zdemolowana przez wieki kolonizacji, w świadomości przybyszów dokonała się jednak istotna przemiana. Autor wiersza wycofuje się ze swoich roszczeń wobec lokalnej kultury, oddaje terytorium w poczuciu, że jego odrębność pozostała obca, i to w dwojakim sensie: jako niepoznana inność i jako własne niezakorzenienie. Mini-poemat $N a d a b w$ Inflantach z perspektywy dyskursu regionalizmu przedstawia dylematy tożsamościowe mieszkańców miejsca, w którym działy się historie różnych narodów i kształtowało się obok siebie kilka kultur. Z kolei z punku widzenia dyskursu kolonialnego i postkolonialnego wiersz prezentuje dylematy autoidentyfikacyjne potomków kolonizatorów, łącznie z ich próbami przełamania kompleksu konkwistadora w stronę uznania inności i pozytywnej dyseminacji kulturowej. Zamiast odpowiedzi na pytanie o tożsamość, pojawia się akceptacja inności, sensu w przekreśleniu, uznanie braku odpowiedzi za odpowiedź. Przybysz odchodzi zapewne ze świadomością, że należało postawić zupełnie inne pytania.

\section{Kazimierz Bujnicki}

Dyskursy inflanckiego pogranicza znalazły swoją poważną reprezentację w powieściach Kazimierza Bujnickiego (1788-1878). Ten zdeklarowany regionalista, gdy zaczął redagować „Rubon”, był już autorem wydanej w Wilnie w 1841 r. Wędrówki po małych drogach. Ta dwutomowa powieść z podtytułem Szkice obyczajowe na pro- 
wincji pokazuje prowincjonalne życie ziemian inflanckich $\mathrm{w}$ formie popularnych wówczas obrazków obyczajowych. Towarzysząca im ostra satyra i przejrzyste klucze personalne spowodowały dość duży, przeważnie negatywny, odbiór powieści w rodzimych Inflantach i przydały pisarzowi opinię złośliwego satyryka ${ }^{19}$. Osnowa fabularna Wędrówki nie wychodzi poza popularne wówczas kanony powieści obyczajowej: narrator i jego przyjaciel Adolf udają się w podróż po okolicy inflanckiej w celach rozpoznawczo-matrymonialnych, związanych z panną swataną temu drugiemu. Już w pierwszym dniu wędrówki spotykają tajemniczą piękność, za którą niezwłocznie się udają, jednak szereg nieprzychylnych okoliczności myli ich drogę, więc niechętnie wracają do pierwotnego celu i odwiedzają ciotkę Adolfa, która chce go wyswatać - jak się później okazuje - właśnie z ową piękną nieznajomą. Pierwszy tom powieści spajają zatem dwa główne wątki: podróżny i miłosny. Podróż jest pretekstem do rozbudowanych opisów życia ziemiańskiego, a także wątpliwej urody prowincjonalnych mieścin inflanckich, $\mathrm{z}$ brudnymi niemieckimi karczmami i wszędobylskimi, nachalnymi Żydami. W drugim tomie Bujnicki więcej miejsca poświęcił krytyce obyczajowości ziemiaństwa (snobizm, nadętość obywateli na urzędach, korupcja, hazard, pieniactwo prawników, miałkość ideowa itp.), rezygnując $\mathrm{z}$ atrakcyjności fabuły na rzecz „obrazków z życia”, przeważnie krytycznych, choć pojawiają się także wśród nich przykłady budujące.

Dyskurs regionalizmu realizuje się w tej powieści w bardzo prostej, oświeceniowej niemal formie. Autor - niewątpliwie utożsamiający się z narratorem, co potwierdzają odpowiednie partie Pamiętnikó $w^{20}$ - wątkiem podróżniczym zakreśla terytorium regionu (bohaterowie podróżują ,po obu brzegach Dźwiny”), a drobiazgowość i przenikliwość w portretowaniu licznych przedstawicieli lokalnej społeczności zaludnia region odrębną wspólnotą. Dochodzi tu do głosu dochodzi intencja ujęcia w ramy sentymentalnej prozy obyczajowej czegoś, co nie ma gotowego kształtu, co jest wciąż szkicem, zbiorem ułamków literackich składających się na Wędrówkę. Widać tu także chęć odróżnienia, społecznego i narodowościowego, polsko-inflanckiej szlachty i nadania jej odrębnego statusu w ramach zróżnicowanej struktury ludnościowej bałtyckich krain. Tendencja ta, według badaczy pogranicza, dotyczy w szerszym pojęciu prozy kresowej, która

określała (...) charakter zachowań jednostek i zbiorowości wobec siebie i wobec obcych. Co istotne, stanowiła zarazem czynnik identyfikacji wewnątrzgrupowej, jak i element odróżniający od innych. Społeczna i ideologiczna rola powieści historycznej wiązała się ściśle z jej zadaniami obronnymi i kompensującymi. Stąd istotnym składnikiem jej fabuł stawały się pola zagrożenia i konfliktu ${ }^{21}$.

${ }^{19}$ Tak o Bujnickim napisał w recenzji z Wędrówki Edward Dembowski w „Przeglądzie Naukowym" $1842, \mathrm{nr} 7$.

${ }^{20}$ K. Bujnicki, Pamiętniki (1795-1875), oprac. Paweł Bukowiec, Kraków 2001.

${ }^{21}$ Tadeusz Bujnicki, Litwa między Wielkim Księstwem a kresami. Powieści historyczne Kraszewskiego na tle dziewiętnastowiecznych wyobrażeń o litewskiej przeszłości [w:] Kultura polityczna w Polsce, 
Zjawisko separowania się zbiorowości kresowych dotyka problemu mentalności pogranicznej. Szlachta polsko-inflancka ma swoje obyczaje, przekonania ideowe, religijne i społeczne, nie pozwala sobie łatwo narzucić cudzoziemszczyzny (ten argument, powtarzający dydaktykę oświeceniową, w przypadkach inflanckich wyraźnie był skierowany także przeciwko kulturze niemiecko-bałtyckiej i protestanckiej). Dyskurs regionalizmu w ziemiańskim wydaniu Bujnickiego wsparty był dyskursami: nacjonalistycznym i wyznaniowym.

Kazimierz Bujnicki należał do reformatorskiego skrzydła szlachty polskoinflanckiej, czego potwierdzeniem są dysputy światopoglądowe w Nowej wędrówce po matych drogach, dwutomowej kontynuacji Wędrówki, opublikowanej w jedenaście lat później w Wilnie. Osnowa fabularna podobnie spoczywa na wątku miłosnym i podróżnym, przy czym ten drugi w jeszcze większym stopniu stanowi jedynie pretekst do opisów obyczajowych. Za całe uzasadnienie kompozycji uchodzi szlachecki obyczaj częstego i spontanicznego odwiedzania krewnych i sąsiadów, obudowany niekiedy lakonicznie sformułowaną „sprawą”. Narrator-autor jest „wędrowcem periodycznym", który lubi po latach odwiedzać te same, bliskie mu miejsca, gdzie „zostawił coś ze swoich myśli” ${ }^{\text {,2 }}$. Podczas jednej z takich wędrówek gości w domu Rotmistrza, który podczas wieczoru towarzyskiego wygłasza wobec demokratycznie nastawionej młodzieży filipikę w obronie arystokracji. Argumenty Rotmistrza nie wykraczają poza standardowy arsenał średnio przygotowanego konserwatysty: że arystokracja od wieków kształtuje tradycję, że daje wzór etyczny i praktyczny, jest stymulatorem cywilizacji i postępu, a przypisywane jej winy są nieuprawnionym uogólnieniem. Krytykowany przez demokratów przepych pozwala wypracować kult piękna, wzniosłości i szlachetnego działania, które to zalety siłą rzeczy promieniują także na klasy niższe:

Formy przyzwoitości urzeczywistniają ideę dobra i piękna, bo co jest rzeczywiście piękne, jest zarazem dobre. Wprowadź w obyczaje przyzwoitość, a staną się dobre, wypędź ją z nich a zdziczeją całkiem. Wyżeń z kraju wszelki przepych, blask, okazałość, a mieszkańcy jego zgnuśnieją, zubożeją, przemysł upadnie, rolnictwo się nie podniesie, a piękne sztuki wnet się zeń wyniosą $a^{23}$.

Można tę argumentację odrzucać na różne sposoby i podważać jej punkty wyjścia, nie można jednak odmówić jej proroczej przenikliwości w obliczu sytuacji w Inflantach Polskich przez następne półtora wieku. Lokalni czytelnicy powieści już kilkanaście lat później byli uczestnikami i świadkami wydarzeń potwierdzających tezę o upadku gospodarki w kraju, skąd „wypędzono okazałość”. Ich skutki, w połączeniu z efektami rewolucji z początku XX wieku widoczne są w Inflantach Polskich do dziś.

t. VI, cz. I pt. Litwa w Polskiej tradycji i kulturze politycznej, red. Marceli Kosman, Wyd. Nauk. INPiD UAM, Poznań 2006, s. 86.

${ }^{22}$ K. Bujnicki, Nowa wędrówka po małych drogach. Szkice obyczajowe, J. Zawadzki, Wilno 1852, t. I, s. 31.

${ }^{23}$ Tamże, s. 100. 
W tej samej dyskusji Rotmistrz jednak broni również równouprawnienia i krytykuje demokrację amerykańską za niewolnictwo, wykazując przy tym, że jest ona skażona tymi samymi wadami, które demokraci przypisują arystokracji. Równość w polityce amerykańskiej uważa za „czcze hasło” i podaje przykłady amerykańskiego przepychu na dowód, że ,żywioł arystokratyczny jest nieśmiertelny i wyobraża toż samo co żywioł cywilizacyjny" (s. 102). W tej apologii nierówności i hierarchii nie jest jednak konsekwentny, skoro w następnych zdaniach ujmuje się za czarnymi niewolnikami Ameryki:

...zdaje mi się, Murzyn jest równym nam człowiekiem, a stąd nie pojmuję, jak można ten kraj zwać ziemią wolności, w którym jeden człowiek ma prawo kłaść na drugiego pęta niewoli, kupować go i sprzedawać jak bydlę, przeto iż tamten ma białą, a ten czarną skórę? (...) Porównaj średniowieczne przywileje seniorów względem swoich wasalów, z przywilejami dzisiejszego amerykańskiego demokraty-filantropa względem swoich niewolników, a ujrzysz różnicę tak wielką, że będziesz musiał nolens volens ująć coś ze swej admiracji dla tego ideału liberalnych instytucji ${ }^{24}$.

Równość dla Bujnickiego dotyczy rasy, ale nie praw obywatelskich. Słowa te zostały napisane dziesięć lat przed wybuchem wojny secesyjnej i trudno odmówić ich autorowi myślenia na owe czasy postępowego. By należycie odczytać intencje autora, trzeba uświadomić sobie presję sytuacji w tamtym miejscu i czasie. Obrona warstw uprzywilejowanych w wydaniu polskiego Inflantczyka połowy XIX w. oznaczała nie tyle wstecznictwo ideowe, co walkę o przetrwanie na terenach traconych politycznie i ekonomicznie. Sprzeczność w postawie Rotmistrza jest tylko pozorna dla polsko-inflanckich reformatorów konieczne było wówczas i przeprowadzenie gruntownych reform społeczno-gospodarczych, i zachowanie wpływów na tamtych terenach. W ramach horyzontu myślowego pisarza alternatywą dla ziem inflanckich nie była powszechna demokratyczna rewolucja, ale rozprzężenie i rusyfikacja. A zatem jeżeli myśleniem tym kierował interes, to nie tylko grupowy, ale i narodowy. Sprzężeniu uległy tu dyskursy: regionalizmu, kolonializmu i nacjonalizmu.

Jeden $\mathrm{z}$ zarzutów wobec pisarstwa Bujnickiego wyprowadzany był $\mathrm{z}$ jego jezuickiego wykształcenia i mentalności, czego dowody znajdowano w kreacji bohaterów, Polaków-katolików. Rzeczywiście, spośród licznych portretów polsko-inflanckich typów charakterologicznych szczególne miejsce zajmują księża. W Wędrówce po małych drogach jest nim ksiądz August, „pasterz otoczony tysiącem prostaczków”, dla którego prototypem z historii Inflant Polskich była zasłużona osoba Michała Rotha $^{25}$. Został on przez pisarza potraktowany bardzo poważnie: do niego należy

\footnotetext{
${ }^{24}$ Tamże, s. 103.
}

${ }^{25}$ K. Bujnicki, Wędrówka..., t. II, s. 6. Michał Roth (1721-1785), jezuita inflancki; nauczył się dialektu łatgalskiego, by móc lepiej rozumieć się z okolicznymi chłopami, którym poświęcił swoją kapłańską działalność. Manteuffel powiada o nim w Zarysach: „Ożywiony duchem Bożym pierwszego apostoła Inflant, błogosławionego Mejnarda, osiadł on na wsi pomiędzy Łotwą, zbliżył się do niej 
moralna ocena faktów, on wypowiada najważniejsze sentencje, on też ma do wykonania poważną misję w Inflantach. W przeciwieństwie do swego pierwowzoru, posiada ksiądz August spory majątek, który w dużej części przeznacza na potrzeby swych wiernych. Jak wyjaśniał Bujnicki w liście do Michała Grabowskiego, plebanowi potrzebne są pieniądze, by mógł skuteczniej wypełniać swe posłannictwo i nie musiał poświęcać tyle czasu na zdobywanie środków do życia. Cały wywód kończy westchnieniem: „Co by to więc było za szczęście, gdyby się dał tu [do Inflant Polskich - K.Z.] namówić jaki ksiądz światły, żarliwy i nie ubogi. Wróciłyby nam jezuickie czasy" ${ }^{26}$. Dlaczego rozwiązani 20 lat wcześniej jezuici byli dla Bujnickiego tak ważni? Czy tę tęsknotę uzasadniało jedynie wsteczne religianctwo?

Podobnie jak w przypadku Konstancji Benisławskiej, przemawia przez Bujnickiego obawa kresowego katolika przed utratą tożsamości, religijnej i narodowej. Przemawia także lęk przed barbarzyńskim wschodem, niszczącym wraz z rzymską wiarą zachodnioeuropejski porządek. Jezuici nie byli narzędziem kontroli w rękach arystokracji, jak to zwykle miało miejsce w sytuacjach kolonialnych. O takim wykorzystaniu jezuityzmu można mówić w przypadku Rygi, ale nie Inflant Polskich. Tutaj w dużo większym stopniu chodziło o narzucenie katolickiej świadomości chłopskim poddanym, w obawie przed ich rusyfikacją. Te dwa czynniki - religijny i narodowy - nie dają się w inflanckiej odmianie dyskursu wyznaniowego oddzielić. Można z powodzeniem założyć szczerość intencji Bujnickiego, który tworząc postać księdza Augusta nakazał mu być zamożnym szlachcicem, by mógł sam finansować kościelne przedsięwzięcia. Chodziło o względną niezależność instytucji kościelnych od szlachty, ale też o oszczędzenie chłopom zbędnych wydatków. Rozwiązanie takie pozwoliłoby utrzymać łotewską społeczność nie tylko przy Kościele katolickim, ale także przy polskiej świadomości narodowej. Pomysł jest jednak ryzykownie utopijny, biorąc pod uwagę znikomą atrakcyjność Inflant Polskich, skąd wszyscy uciekali na posady bliżej ,centrum”. „Obyczajność i pobożność” miały być tarczą przeciwko zdziczeniu obyczajów i przeciwko rusyfikacji. Jak się w następnych dekadach okazało - tarczą w obu przypadkach niewystarczającą.

Problem nieokreślonego religijnie chłopstwa musiał być dla Bujnickiego istotny, skoro w Pamiętnikach księdza Jordana stworzył również bardzo poważną i doniosłą postać jezuity, księdza Anzelma, poświęcającego się przede wszystkim pracy misjonarskiej, dla którego najwyższy cel kapłańskich usług stanowiła „męczeńska palma". Przedmiot jego chrystianizacyjnych zabiegów - łatgalski włościanin - został przez narratora scharakteryzowany następująco:

pojęciami i duszą. Słodki i łagodny odwiedzał chałupy, pocieszał chorych i leczył; grzesznikom przynosił słowo zbawienia, pamiętał o potrzebach doczesnych ludu, który raz na zawsze pozyskał dla Kościoła. (...) Księdza Michała Rotha zwano powszechnie apostołem łotewskim” [Z, 188-189]. Porównując Rotha do Meinharda Manteuffel potwierdza wielokrotnie powtarzaną przez siebie tezę, że w XVIII, a nawet jeszcze XIX wieku chrystianizacja nie była procesem zakończonym.

${ }^{26}$ M. Grabowski, Korespondencja literacka, T. Glücksberg, Wilno 1842, cz. I, s. 52. 
Łagodnego z natury charakteru a tępego rozumu, dziwnie jest łatwowiernym; pobożność tedy jego połączona jest z zabobonnością. Nawrócony do wiary chrześcijańskiej nie mógł się w ciągu wieków pozbyć zabytków dawnego pogaństwa. Wierzy ślepo w to wszystko, co Kościół podaje do wierzenia, ale też równie ślepo wierzy w gusła i wilkołaki. [R I, 149]

Pogańskie skłonności poddanych, ich łatwowierność i chwiejność przekonań wciąż budziły niepokój głównego bohatera. Problem dotyczył nie katolickiego wyznania czy polskiego patriotyzmu - wiązał się z poczuciem obcości i niepewności na własnej ziemi. Łatgalski poddany był dla polskiego pana nieprzewidywalny i dlatego budził lęk. To z jego powodu ziemia inflancka kryła nierozpoznaną zagadkę, której należało się obawiać. Podobnie jak podmiot poematu Michała Borcha, narrator Bujnickiego odczuwa ziemię rodzinną zarazem jako swoją i obcą zarazem, dlatego kurczowe trzymanie się jezuickiego misjonarstwa jako moralnego i społecznego panaceum było próbą ratowania własnej zagrożonej tutejszości, szukaniem lokalnej identyfikacji. Dyskurs wyznaniowy, podobnie jak kolonialny i regionalny, służył konstytuowaniu polsko-inflanckiej tożsamości, który to proces nie mógł zakończyć się sukcesem właśnie dlatego, że błądził w cyrkulacji dyskursów.

Proza Kazimierza Bujnickiego nie przetrwała próby czasu i została odłożona do lamusa z etykietką „,konserwatyzm ziemiański”, przypiętą jej przez pozytywistycznych krytyków. Jej dyskursywna zawartość nie mieściła się w ideowym programie epoki i przegrała z myśleniem ,centralnym”. To, co ją kształtowało, czyli specyfika lokalna oraz presje mentalnościowe polsko-bałtyckiego pogranicza, nie zostało odczytane, lub też zostało zdyskredytowane przez wymogi nowoczesnych dyskursów ideowych. Ideologia Polaków inflanckich nie miała swej wyrazistej wspólnoty, mogącej zaakceptować i tym samym uwiarygodnić wbudowane w nią perspektywy. Mówiąc inaczej, proza Bujnickiego nie miała dostatecznej mocy sprawczej, by uruchomić odpowiedni krąg odbiorców. Broniąc zarazem arystokracji i reform, jezuityzmu i postępu technicznego, zdradzając przywiązanie do rodzimości i równocześnie lęk przed nią - Bujnicki nie mógł liczyć na zrozumienie w Warszawie czy Krakowie. Większym pojęciem o kulturowym zapleczu pisarza wykazało się Wilno, gdzie znalazł on wydawców i życzliwych recenzentów. Środowiska kresowe generalnie znacznie wnikliwiej odczytywały dzieło dagdzieńskiego literata, dużo lepiej orientując się w ciężarze lokalnych okoliczności i znaczeniu tego, co stanowi o odrębności regionu. Tam też dokładniej orientowano się w zagrożeniach, jakie płyną dla miejscowych społeczności ze strony nieznanego, nieoswojonego, nieobliczalnego otoczenia.

\section{Uroki Dźwiny}

Wspomniano już przy okazji poematów Gercike i Na dąb w Inflantach, że w poezji polsko-inflanckiej silnie do głosu dochodzi niepokój związany z obcością miejsca - własnego, rodzimego miejsca, które wymyka się oswajaniu i pozostaje niepo- 
jęte. Inflancki dyskurs sentymentalizmu składa się z rzeki i lasów - dwóch znaków nieprzystępności i dzikości, organizujących poetyckie pejzaże. Zwróciła na to uwagę Agnieszka Durejko, układając antologię poezji polsko-inflanckiej pod znamiennym tytułem Polskie wiersze znad Dźwiny, która właściwie stanowi wybór wierszy o Dźwinie. Sporo tam nawiązań do Mickiewicza i jego romantyzmu litewskiego, a konkretnie do jednego wiersza, jak wyraźnie sugeruje Tadeusz Lada Zabłocki w Do Dźwiny:

Rodzinna rzeko! ileż lat ubiegło,

Gdym nad twym brzegiem dumał raz ostatni;

I złożył jadąc w krainę odległą

Na twojej fali pocałunek bratni.

(...)

Wszystko to przeszło!... łzy me tylko płyną,

Czemuż, o serce, nie stwardziałoś moje?

Czemuż pełnego nadziei, o Dźwino!

Mnie nie połknęły bystre nurty twoje? ${ }^{27}$

Jak wiele innych ze zbioru, wiersz czytelnie nawiązuje do Mickiewiczowskiego sonetu Do Niemna („Niemnie, domowa rzeko moja...”), godny odnotowania jest natomiast fakt, że pożegnanie z miejscem urodzenia, symbolizowanym przez rodzinną rzekę, pojawia się niemal w każdym wierszu antologii. Rzeka jest świadkiem odejścia, utraty, przepadku życia, przemijania, niespełnienia, krótko mówiąc - egzystencjalnych lęków. Antoni Kruman w swojej próbie „rzecznej elegii” wprost adresuje do Dźwiny prośbę o pamięć:

Jeszcze może upłynąć lat i miliony,

Jeszcze niejeden widok przed tobą zabłyśnie;

Ty jesteś nieśmiertelną, a mnie śmierć uściśnie:

Pomnijże, jakem w brzegu twym siedział zdumiony. [PWD, 29]

Odejście jest i dosłowne, i symboliczne. Poeta porzuca krainę dzieciństwa, miejsce własne, mityczne odniesienie - ale także konkretne terytorium, podpisane imieniem rzeki. Przez Mickiewiczowską kliszę przebija indywidualne doświadczenie miejsca (w tym akurat przypadku białoruskiego Połocka), słabo zarysowane, wtopione $\mathrm{w}$ wiele podobnych prób, skazane niejako z góry, przez wybór formy poetyckiej, na przegraną. Ciekawsze są przypadki, gdy poeci - świadomi nieuchwytności tego doświadczenia:

Zwodnico!... dla każdego chłodnie przymilona,

A przecież zawsze tęskna! powiedz, ulubiona,

Jaka myśl tak potężnie pierś twą okowała,

${ }^{27}$ A. Durejko, Polskie wiersze znad Dźwiny..., s. 25-26. Dalej jako PWD, z podaniem strony. 
Że ty głosów nie baczysz, ni lutni zabiegu,

Choć te nieraz cię chciały ukołysać w biegu? [PWD, 21]

- próbują dociekać oporu materii i natrafiają na obcość, za którą skrywa się nieszczerość, by nie powiedzieć, zdrada:

Myśl wszakże, pomna głosek, owego imienia,

Co kochanek, lud znikły, twemu nadał stoku,

Myśl odtąd drugich imion już nie chce uroku:

Brzegom tylko powierza starej nazwy brzmienia! -

A brzegi, co nawykły żalom wtórzyć skrycie,

(...)

Wciąż wołają za tobą: Daugava! Daugava!... [PWD, 22]

Autorem wiersza, zamieszczonego w trzecim tomie „Rubonu”, jest znany nam już z poematu Gercike Michał Borch, i odnajdziemy tu znane nam lęki przed nieodgadnionym. Jest w uporczywym stawianiu Dźwiny w centrum poetyckich zainteresowań coś z pogańskiego kultu dla lokalnego bóstwa, co można odczytywać jako etnologiczną fascynację, ale także solidarność z pierwotnymi mieszkańcami (to oni wołają na rzekę jej łotewskim imieniem). A zatem znów powraca problem tożsamości. Odwołując się do obcej nazwy bóstwa poeta wskazuje na granice języka, nieprzekraczalne, i zgłasza niewyrażalność tego, co w doświadczeniu z rzeką wydaje mu się najistotniejsze. Naddźwińskie motywy - własne i cudze zarazem - nie układają się w sensowny, czyli przyjazny pejzaż; miejsce nie podlega oswojeniu, intymność została wystawiona na działanie „niesamowitego”.

\section{Olga Daukszta}

„Niesamowite” wpisane w sentymentalny krajobraz stało się jednym z dominujących motywów poezji Olgi Daukszty (1893-1956), chyba najbardziej inflanckiej z polskich poetek, czego najwybitniejszym dowodem jest tomik Dźwina o zmierzchu z roku 1930. Jej inflanckość zaczyna się już w deklaracji narodowościowej, skomplikowanej jak sama kraina:

Nie jestem Rosjanką, ani prawosławną, jak niektórzy myślą. Jestem katoliczką ochrzczoną w Ryskim kościele (...). Nazwisko moje jest żmudzkie, a może tatarskie (...), myślę, że jestem w zgodzie ze swym imieniem i nazwiskiem, tylko mniej tu wikingów i prusów, ale przeważają Żmujdzini, Jadźwingowie, Tatarzy... Wszak i ja mam kose oczy, szerokie plecy, nieduży wzrost (...). W rodzinie mojej nie brak przyzwoitych nazwisk polskich i niemieckich (...). Piszę po polsku i lubię Polaków, bo byli zawsze dla mnie dobrzy, czego nie mogę powiedzieć o innych narodach, z którymi mnie życie zetknęło ${ }^{28}$.

${ }^{28}$ Kazimierz Andrzej Jaworski, W kręgu Kameny, Wyd. Lubelskie, Lublin 1965, s. 131-132. 
Pisanie po polsku i polska tożsamość były wyborem Daukszty, co w przypadkach pogranicznych należy do reguły. Urodziła się w Rydze i tam uczęszczała do polskich szkół, w tym do słynnej pensji Emilii Lichtarowicz, gdzie nabyła sprawności językowej i ogłady literackiej. Wypieranie się rosyjskości ma ciekawy kontekst: pod koniec życia poetka, mieszkając w Dyneburgu, pisała po rosyjsku prośby o pracę, której zresztą jej odmawiano i umierała w 1956 r. właściwie w nędzy. Jej twórczość przepadła w kulturze polskiej, podobnie jak całe Inflanty, a tym bardziej nie było dla niej miejsca w sowieckiej republice łotewskiej.

Wydaje się, że dzięki wewnętrznej niezależności i mocnego osadzenia w odrębności inflanckiej, Daukszta uniknęła powszechnego w przypadkach kresowych ciągłego potwierdzania wspólnotowej identyfikacji, co odnajdujemy u większości pisarzy kresowych. Powyższa deklaracja przynależności do kultury polskiej stanowi zarazem własne zaprzeczenie, skoro o Polakach powiada „oni”, jak o życzliwych panach kolonizatorach. Jej świadomość wydaje się wyrastać ściśle z wielowiekowego doświadczenia bałtyckiego, w którym nie było miejsca na jednoznaczne przyporządkowania etniczne, a znacznie silniej działała mentalność „tutejsza”. Jej poezja nosi dokładnie takie właśnie znamiona tutejszości i ściśle wpisuje się w inflancki pejzaż. Jest surowa jak sama kraina: szara, nieprzyjazna, z groźną rzeką pośrodku:

Inflanty - kraj sosen spalonych wśród piasków, ląd ptaków przelotnych, wrzosowisk i lasków.

Szum lodów wiosennych z Wałdajskiej wyżyny i pomruk przekorny burzliwej w dzień Dźwiny.

Kraj szary, siermiężny, ciąg wichrów z wybrzeża morskiego i tęsknot za dalą, ostrożność rubieża, przewrotna pokora i piaskiem zawiana głąb ziemi gorącej, jak serce wulkana, [ Inflanty]

Sentymentalizm to surowy, w jakimś sensie wrogi (spalone sosny, burzliwa Dźwina), daleki od przywołania łatwego kiczu. Związek z otoczeniem przebiega głęboko, w tych warstwach emocjonalności, gdzie wzruszenie zastąpione zostaje przez szorstkie, odpychające zgrubienie. Dopiero w tak zindywidualizowanym otoczeniu podmiot ustanawia swoją identyfikację, jakby w przekorze czy zniechęcaniu innych poetka chciała zawłaszczyć całość dla siebie: „I nigdzie piękniejszym się niebo nie zdaje/ wśród deszczów gwiaździstych, jak w szarym tym kraju”.

Potwierdzeniem tej strategii „oszpecania” własnego pejzażu jest wiersz Dźwina, zaczynający się od słów: „Nie jest rzeką wierną, lecz zmienną, zazdrosną,/ Piękno swe ukrywa pod świtką z samodziału". Odzywa się tu topos wtajemniczenia: piękno rzeki rozpoznają tylko ci, którzy mogą dostrzec je pod mylącymi przesłonami, czyli tutejsi, obcujący z nią i doświadczający jej zdradliwych kaprysów. Wciągająca jest jej uroda, niebanalna i niebezpieczna, jak urok przebiegłej wiedźmy z bajki. Rzeka wyobrażająca krainę - zagraża najbardziej swoim wielbicielom: 
Otworzy szkarłatne zamki na dnie. Uderzy w dzwony.

I zbrzydnie ci wszystko oprócz niej na ziemi, jak kamień na jej brzegu staniesz w nią wpatrzony,

niepotrzebny nikomu na świecie i na zawsze niemy. [Dźwina]

Daukszta w projekcie sentymentalizmu obrała drogę dosyć przewrotną. Kultura jest siecią transakcji, ale same uczucia, stojące u źródeł poezji, są nietransakcyjne. Miłości do dzikiego i nikomu nieznanego, prowincjonalnego pejzażu nie da się przełożyć na nic innego; Dźwina wciąga i gubi, a poezja nie oferuje żadnych modeli do przekazania tak intymnego doświadczenia. Pozostaje jedynie zgłaszanie dziwności, bezskutecznie szukanie dróg ucieczki. Język wierszy jest polski, ale na tym się ich polskość kończy, gdyż samego doświadczenia na style tego języka przełożyć nie można. I Daukszta pisze po polsku niepolską, oryginalnie inflancką poezję.

Jednym z najdziwniejszych wierszy Daukszty jest It dźwiński, zaczynający się od słów „Najgorsze są takie oczy jak dno naszej Dźwiny”, gdzie wzajemne przenikanie się pejzażu, emocji i myśli osiąga jakieś psychodeliczne niemal pomieszanie:

Strzeż się tych oczu zielono-złoto-szaro-piwnych:

w nich szał dźwińskiej wody, gdy się kruszą lody

wezbrane, gwałtowne; stopione w nich rozbójnicze grzywny,

za które przepite - młodość, miłość, talent i dola.

Dlatego ta woda tak pali; zmartwychwstają żale.

Uciekaj od tych oczu w szerokie, wielkie pola!

Fragment ten jak w soczewce skupia fundamentalne składniki inflanckiej mentalności; nie polsko-, łotewsko-, czy niemiecko-inflanckiej, ale właśnie inflanckiejniedookreślonej, zbudowanej na żalu, oszustwie, obłędzie, przegranej, ucieczce. Może najtrafniej to lokalne, egzystencjalne doświadczenie da się ująć słowem „przekleństwo”, zawierającym cały fatalizm niechcianej, a prawdziwej miłości:

Inaczej... - zamiast wina, miłości... Jeśli świat ci miły,

nie trzeba marzyć, bo może się zdarzyć:

z oczu tych, jak z dna dźwińskiego, łykniesz tylko iłu.

Tak wygląda w Inflantach das Unheimliche, niesamowitość nieprzekładalnego losu, przygnębiający, egzystencjalny pitoresk. Daukszta nie próbuje dostosować się do wymogów „literackości”, zachowuje krytyczny dystans i świadomie pisze wiersze zamknięte w hermetycznej, lokalnej przestrzeni. Miłość i sens losu znajdują rozwiązanie na dnie rzeki, od jednego i drugiego nie ma ucieczki, tak jak nie można porzucić miejsca, nawet jeśli jest ono zarazem własne i obce. Dyskurs sentymentalny zostaje zakłócony nierozwiązalną łamigłówką egzystencji, splecionej z sytuacją pograniczną.

W poezji Olgi Daukszty regionalizm Inflant Polskich znalazł swój najbardziej oryginalny wyraz i jej przepadek w kulturze polskiej jest co najmniej symptoma- 
tyczny. Wydane później Błękitne inicjały (Dyneburg 1933) oraz Walet kierowy (Lublin 1937) nie dorównują siłą poetyckiego obrazowania Dźwinie o zmierzchu, jakby zabrakło im tego istotnego związku z miejscem, organizującego debiutancki tom. Złożony przekaz wierszy o krainie naddźwińskiej staje się czytelny wyłącznie w kontekście tamtejszej, lokalnej kultury, determinującej perspektywę podmiotu. Nieobecność wierszy Daukszty w dzisiejszej literaturze polskiej, w czasach, gdy zanikło podłoże kulturowe ich lokalizacji, dowodzi nie tylko tego, że trudno czytać literaturę pogranicza bez jej miejscowych kontekstów. Ważniejsza wydaje się nieczytelność pewnych projektów egzystencjalnych w nią wpisanych, prób samookreślania poprzez umiejscowienie - nazywania losu przez pejzaż. Daukszta wyobraźnią lokowała się na brzegu Dźwiny, o zmierzchu, gdy oszałamiające kolory gasnącego nieba zapowiadały to, co zapowiadają wszędzie i zawsze, a jednak coś bardzo własnego: rychły mrok. Jak w wierszu Refleksy zmierzchu, gdzie ,ja” i „obcy” to jedno:

Przed chwilą zmierzchu - na niebie purpurowe miasta, na wodach Dźwiny - granatowe, czerwone łabędzie, a przed progiem mego domu - z latarką niewiasta o twarzy zakrytej wśród milczącej, ponurej gawiedzi. (...)

Podchodzę do okna... Kobieta $\mathrm{z}$ dala potrząsa latarką, w szkłach jej - łabędzie Dźwiny, czerwień semaforu... Spoglądam w twarz niewieście... ta cofa się szparko... W płachcie jej - próżnia grobów i głębia wieczoru...

\section{Kazimiera Iłakowiczówna}

Literatura polsko-inflancka miała swoją uznaną poetkę klasy ogólnopolskiej, a była nią Kazimiera Iłłakowiczówna (1889?-1983). Urodziła się w Wilnie, ale wychowywała u Zyberk-Platerów w majątku Baltyń, niedaleko Krasławia, dokąd zabrała ją przybrana matka, Zofia Zyberk-Plater Buynowa. Inflanckość znalazła swój wyraz głównie w tomiku Popiót i perty z 1930 r., ale jej zrozumiałą obecność odnajdziemy również we wspomnieniach zawartych w Niewczesnych wynurzeniach (Warszawa 1958). Inflanckość jej wyobraźni jest nie tylko domniemana - w wielu wierszach pojawiają się konkretne nazwy geograficzne, Inflanty Polskie mają tam swoją wyraźną sygnaturę. A mimo to biografowie Iłłakowiczówny zwykli tę część jej lokalnego doświadczenia kwitować mianem: północna Litwa.

Inflanckie wiersze Iłłakowiczówny układają się w cykl rodzajowych obrazków z miejscowymi rzekami, lasami, miasteczkami, wsiami, cmentarzami itd. Można by z nich skomponować grottgerowską serię o surowych, najdalszych, niemal skandynawskich kresach. Regionalizm wprowadzają nazwy, nic niemówiące, brzmiące jakby nie po polsku: 
Indra - wartka śród spadzistych brzegów.

Raudawizka - w łąkach ścieg przy ściegu,

i odnoszące się do egzotycznych rzek, które zbiegają się ku Dźwinie:

I pamiętam rozlew nad rozlewy,

zatopione brzegi, łąki, krzewy

i czajki wiosenne i kry, które płyną

wszystkie do Dźwiny. [Moje rzeki]

Wiersz jednoznacznie wprowadza indywidualne doświadczenie pejzażu przez użycie niepowtarzalnych i niezrozumiałych nazw. Podobnie pozbawione desygnatu dla niewtajemniczonego czytelnika są nazwy własne w wierszach Dwa kościoły (Indryca i Warnowicze), Inwokacja (Dźwińsk, Mołodeczno), Cmentarz w Jurahowie (Jurahów, Baltyn), a także Sztarnberg, Liksna, Murowanka, Przydrujsk, Ruchmany, Dorotpol itp. Iłłakowiczówna buduje swój poetycki mit miejsca świadomie jako teren zakryty, niedostępny, leżący gdzieś „poza”. Mieszkańcy tego regionu także zostali sportretowani w miniaturowych obrazkach, w których poetka stara się uchwycić specyfikę: "Starowier Wasyl z synami ośmioma/ skrzypiące antonówki zsypywał na słomę” (Starowiery); ,wychodzili na wierzch kupcy z głębokich kramów,/ chwiali się na nogach cienkich” (Kupcy w Krasławiu); „Kacapi jedzą powoli pod jabłonią/ barszcz okazały, kapustę pełną woni” (Kacapi); „Nie uwierzycie, choć wam opowiem:/ żył Wacław w całym lesie, leśny człowiek" (Wacław). Nie dba ona o zrozumiałość i transparentność tekstu, skupia się na rodzajowości miejsc i ludzi jako wartości autonomicznej, niepodlegającej przeniesieniu w szerszy, bardziej zrozumiały dyskurs. Przeciwnie: częściowa nieodcyfrowalność desygnatów jest świadomym wyborem artystycznym. Iłłakowiczówna nie podejmuje żadnych prób przekładu tych lokalnych sensów na bardziej ogólne pojęcia kulturowe, odmawia kulturowej translacji z braku i możliwości, i potrzeby. Więcej nawet: zakreśla wyraźne granice wspólnoty, dla której pisze, jak w znacząco zatytułowanym wierszu Nie dla obcych:

Ten las, ten ogród, ten dom, te porosłe cząbrem manowce

- to nie są wiersze dla was, to nie są wiersze dla obcych!

Stoją tu czcionki zaklęte, grządkami na stronicach, ale ten, kto to żywcem spamiętał, tylko ten się może zachwycać.

To wyodrębnienie wspólnoty odbywa się w kilku wymiarach, bądź też - mówiąc naszym językiem - w kilku rozmaitych dyskursach. Szczególnie uderzającą 
kombinację dyskursów patriotycznego, etnicznego, wyznaniowego, społecznego i postkolonialnego stanowi wierszyk Tamtejsi:

Jacyż to nasi tamtejsi?

Bledsi, chudsi, lżejsi, mniejsi.

Piechotą na jarmark idą,

by ich podwiózł - proszą Żyda;

służą starowierom jak parobcy,

nie strzyżeni, niepiśmienni... Ciche owce!

(..)

Hostia nad nim wzniesiona jaśnieje niezwykle...

O święci, nieznani święci Łotwy i Litwy!

Pewne frazy $\mathrm{w}$ tym wierszu pozostaną niezrozumiałe, jeśli nie uwzględnimy w odczytaniu całej złożonej i trudnej sytuacji polskiej mniejszości w międzywojennej Łotwie. „Nasi tamtejsi” oznaczają polsko-katolicką mniejszość Łatgalii, która zepchnięta została do roli słabo tolerowanego etniczno-wyznaniowego marginesu. Bieda i niska ranga społeczna spotęgowane zostały napięciem religijnym (,,proszą Żyda”, ,służą starowierom”) i marginalizacją kulturową (,nie strzyżeni, niepiśmienni”). Przez „gorszość” Polaków łatgalskich przebija w słowach Iłłakowiczówny perspektywa postkolonialna: tutejsi służą przybyszom, co stoi - delikatnie mówiąc w pewnej niezgodności z faktami. Co ciekawe, bardzo podobnie przedstawiani byli - także jako tutejsi i krzywdzeni przez innych - chłopi łotewscy w literaturze XIX w. Ten sam dyskurs postkolonialny służył do formułowania skargi na obcych przez różne, zantagonizowane grupy etniczne.

Martyrologia Polaków w dawnych Inflantach Polskich wyrażona została w dwóch porządkach: patriotycznym i religijnym. Godny odnotowania jest także fakt, że Iłłakowiczówna wraca do swego dzieciństwa, czyli czasów przedrewolucyjnych, nie wiadomo zatem, czy w kryterium „tutejszych” przeważają względy religijne, czy narodowościowe. Odpowiedź na tę kwestię zresztą niewiele wniesie „tutejsi” są odniesieniem wspólnotowym dla podmiotu, wariantem wybranej identyfikacji etnicznej.

Niedookreśloność inflanckiej tożsamości, rozproszonej i niemożliwej do uchwycenia, znalazła swoje apogeum w niepozornym wierszyku pt. $O$ byt, zbudowanym jak średniowieczny spór o uniwersalia:

„Chcę być koniecznie nazwany!”-

„Jesteś nieznany” -

„Tak, lecz me miano, skoro je wymówisz,

podobne będzie jasnemu błyskowi,

wywiedzie mnie z niebytu, w którym mnie zostawia

nawet i własna pamięć”. - „Jesteś spod Krasławia.

Nic więcej nie powiem. Będziesz w cieniu stał, nikomu niewiadomy, nieznajomy kształt". 
Trafnie wiersz ten podsumowuje rozważania o odrębności i słabej reprezentacji Inflant Polskich w naszej kulturze . Kto pochodzi spod Krasławia - niegdyś uroczego miasteczka na zakolami środkowej Dźwiny, majątku inflanckich Platerów - nie zdoła nigdy sformułować sensownie swojej konstytucji podmiotowej. Pozostanie „w cieniu”, poza definicjami wyrażalnymi w dyskursywnym języku. Indywidualne doświadczenie miejsca, rodzimości jest nieprzekazywalne, a co za tym idzie - podmiot tego doświadczenia nie istnieje. „Błysk”, który wywiedzie z niebytu, podobny epifanii, utrwala to, co poszczególne i niedostępne w jakiejkolwiek formie językowej. Wymówienie zaklęcia, które miało powołać do istnienia („,skoro je wymówisz”) obraca się przeciwko, przekreśla oczekiwanie i odbiera nadzieję. Fraza „Jesteś spod Krasławia" wywołuje efekt odwrotny do zamierzonego: dezintegruje podmiot, pogrąża w niebycie. Obrysowanie konturów własnej egzystencji poprzez identyfikację $\mathrm{z}$ miejscem jest niemożliwe, a zwłaszcza w tym konkretnym przypad$\mathrm{ku}$, przypadku inflanckim, sygnowanym nazwą małego prowincjonalnego miasteczka na końcu świata. Kto wypowiada zaklęcie? Bóg? Los? Sama poetka? Nie ma to większego znaczenia. Każda z perspektyw przynosi tę samą prawdę, zaprzeczoną, przekreśloną w „niewiadomym” i „nieznajomym”.

W studiach kulturowych i geopoetycznych lubimy twierdzić, że nazwanie swego miejsca na ziemi dookreśla tożsamość, ale przypadek inflancki jest inny, by nie powiedzieć - odwrotny. Kiedy polski Inflantczyk/polska Inflantka wypowiada swoje miejsce, pozostaje w cieniu. Więcej nawet - pogrąża się w nim jeszcze bardziej. Odniesienie przestrzenne nie wnosi sensu, lecz go znosi, eliminuje. Cała literatura polsko-inflancka jest opowieścią o niemożliwym zaistnieniu, tam, na kresach kresów, na pograniczu wielu kultur, gdzie każdą tożsamość demontuje od wewnątrz zwątpienie, a od zewnątrz - niesamowitość. Jest też opowieścią o poszczególnym wariancie ogólnego wzoru egzystencjalnego - zagubienia człowieka w świecie; świecie oswajanym i ciągle groźnym, bliskim i nierozpoznanym, na przemian zawłaszczanym i traconym na rzecz Innego. Inflanty Polskie dają nam przykład lokalności, której specyfika może przekładać się na uniwersalną prawdę, ale nie musi. Po drugiej stronie doświadczenia kulturowego polskiej inflanckości leży jednostkowa, niepowtarzalna opowieść o dziwnym i przepadłym już środowisku kulturowym na dalekich, północno-wschodnich kresach dawnej Rzeczypospolitej, gdzie to, co lokalne w fascynujący i niemożliwy do rozwikłania sposób splotło się z tym, co ogólne. 